\title{
SUMMER 1999
}

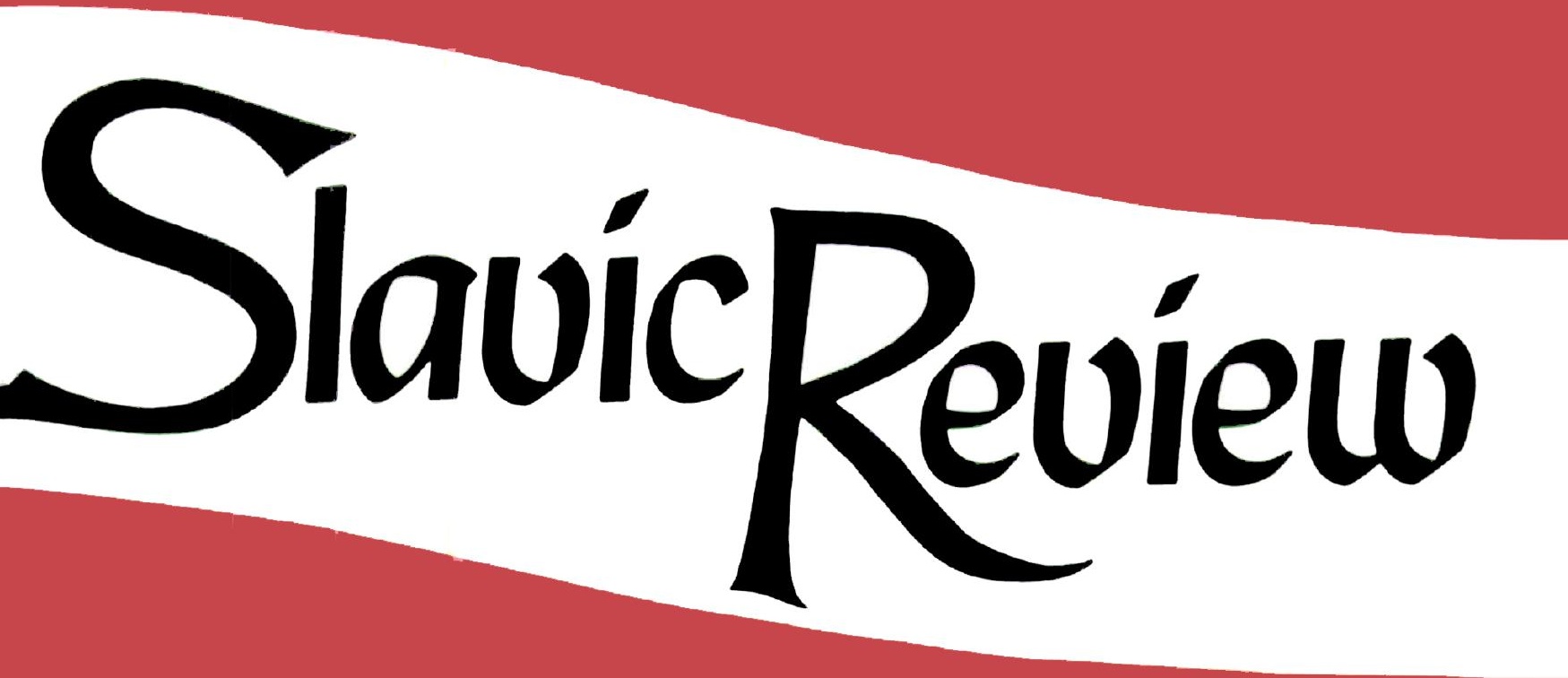

AMERICAN QUARTERLY OF RUSSIAN, EURASIAN, AND

EAST EUROPEAN STUDIES

\author{
SPECIAL ISSUE \\ ALEKSANDR PUSHKIN 1799-1999 \\ Stephanie Sandler, Guest Editor
}

Introduction by Stephanie Sandler

\section{ARTICLES}

Alexander Dolinin : Historicism or Providentialism? Pushkin's History of

Pugachev in the Context of French Romantic Historiography

Sergei Davydov : The Ace in the "Queen of Spades"

David Shengold : Adding to the "Guest" List:

Hugo's Mernani and Pushkin's Don Juan

Catharine Theimer Nepomnyashchy : Pushkin's The Bronze Horseman and Irving's "The Legend of Sleepy Hollow":

A Curious Case of Cultural Cross-Fertilization?

James L. Morgan IV : Love, Friendship, and Poetic Voice in Aleksandr Pushkin's Lycée Elegies

Ian M. Helfant : Pushkin's Ironic Performances as a Gambler

Leslie O'Bell : Writing the Story of Pushkin's Death

Wendy Slater : The Patriots' Pushkin 


\section{EDITOR}

Diane P. Koenker

ASSOCIATE EDITOR, JANE T. HEDgeS

EDITORIAL ASSISTANTS

Stephen M. Herzog Heather L. Tafel Rebecca Barnes Weitzenhoffer

EDITORIAL BOARD

History

Barbara Alpern Engel, University of Colorado $\bullet$ Gregory L. Freeze, Brandeis University $\bullet$ Daniel H. Kaiser, Grinnell College $\bullet$ Lynn Mally, University of California, Irvine $\bullet$ Lewis H. Siegelbaum, Michigan State University • Maria Todorova, University of Florida

\section{Literature and Linguistics}

Clare Cavanagh, Northwestern University $\bullet$ Susanne Fusso, Wesleyan University • Beth Holmgren, University of North Carolina $\bullet$ Harriet Murav, University of California, Davis $\bullet$ Irina Paperno, University of California, Berkeley • James von Geldern, Macalester College

\section{Social Sciences}

Valerie Bunce, Cornell University $\bullet$ Richard E. Ericson, Columbia University • Michael D. Kennedy, University of Michigan • Gail Kligman, University of California, Los Angeles • Philip Roeder, University of California, San Diego

The editors assume no responsibility for statements of fact or opinion made by contributors.

Slavic Review (formerly The American Slavic and East European Review) is published quarterly by the American Association for the Advancement of Slavic Studies, Inc., and is sent to all association members. Members also receive Nerws Nel, the AAASS newsletter. Membership is open to individuals interested in Slavic studies and the study of the non-Slavic peoples of eastern Europe and Eurasia. Applications for membership are accepted by the AAASS, 8 Story Street, Cambridge, MA 02138; (617) 495-0677.

Membership Dues: salary $\$ 10,000-\$ 19,999-\$ 25.00 ; \$ 20,000-\$ 29,999-\$ 40.00 ; \$ 30,000-\$ 39,999-\$ 50.00$; $\$ 40,000-\$ 49,999-\$ 60.00 ; \$ 50,000-\$ 59,999-\$ 70.00 ; \$ 60,000-\$ 69,999-\$ 80.00 ; \$ 70,000$ or more $-\$ 90.00$. Joint members with one subscription to Slavic Review, add $\$ 20.00$ to dues of higher paid member. Dues for students or those with salaries under $\$ 10,000$ are $\$ 25.00$. Subscriptions without membership are $\$ 60.00$. Single current issues and back issues to subscribers are $\$ 20.00$; for members, $\$ 15.00$ each. For overseas postage, please add $\$ 20.00$. Correspondence regarding membership, subscriptions, changes of address, or items for News Net should be sent to the AAASS headquarters at Cambridge.

Articles, books for review, and correspondence concerning editorial matters or advertising should be sent to Slavic Review, University of Illinois at Urbana-Champaign, 57 E. Armory Avenue, Champaign, IL 61820. Telephone: 217-333-3621; fax: 217-333-3872; e-mail: slavrev@uiuc.edu. Technical requirements for manuscript submissions may be found at the end of the advertising section or at our web site: http://www. econ.uiuc.edu/ slavrev.

Published by the American Association for the Advancement of Slavic Studies, Inc. Text set in Baskerville by G\&S Typesetters, Inc., Austin, Texas. Printed by Science Press, Ephrata, Pennsylvania. Second-class postage paid at Boston, Massachusetts. POSTMASTER: Send address changes to AAASS, 8 Story Street, Cambridge, MA 02138.

Articles appearing in this journal are abstracted and indexed in Historical Abstracts, America: History and Life and $A B C$ Pol Sci: A Bibliography of Contents.

Slavnc Review is published at the University of Illinois at Urbana-Champaign, with support from the College of Liberal Arts and Sciences, the Graduate College, the Russian and East European Center, the Department of History, and the Humanities Council.

Copyright $\odot 1999$ Slavic Review ISSN 0037-6779 by the American Association for the Advancement of Slavic Studies, Inc. Permission to reprint must generally be obtained from the association's office. Copying is permitted in accordance with the fair use guidelines of the US Copyright act of 1976. The association permits the following additional educational uses without permission or payment of fees: academic libraries may place materials from Slavic Review on reserve (in multiple photocopied or electronically retrievable form) for students enrolled in specific courses; teachers may reproduce or have reproduced multiple copies (in photocopied or electronic form) for students in their courses. Those wishing to reproduce material from Slavic Review for any other purpose (general distribution, advertising or promotion, creating new collective works, resale, etc.) must obtain permission from the association. 


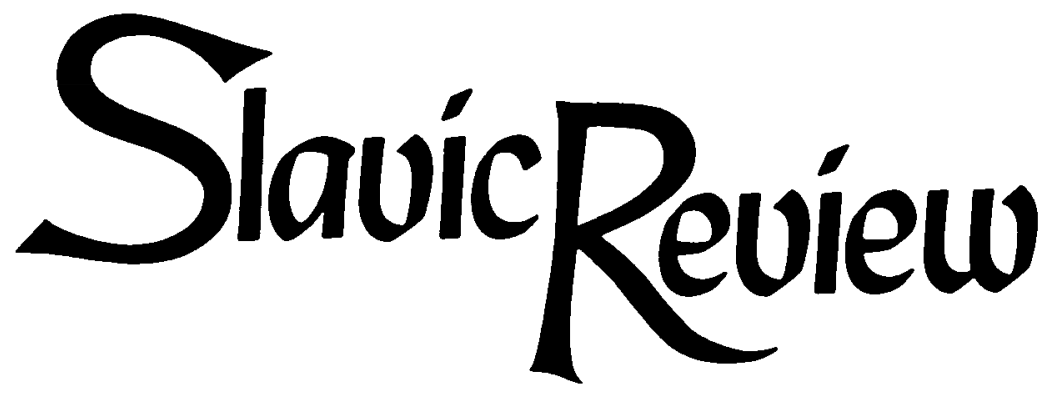

\section{AMERICAN QUARTERLY OF RUSSIAN, EURASIAN AND EAST EUROPEAN STUDIES}

VOLUME 58 NUMBER 2 • SUMMER 1999

SPECIAL ISSUE

ALEKSANDR PUSHKIN 1799-1999

Stephanie Sandler, Guest Editor

\section{CONTRIBUTORS}

vi

Introduction

283

STEPHANIE SANDLER

\section{ARTICLES}

Historicism or Providentialism? Pushkin's History of Pugachev in the Context of French Romantic Historiography ALEXANDER DOLININ

The Ace in the "Queen of Spades" SERGEI DAVYDOV

Adding to the "Guest" List: Hugo's Hernani and Pushkin's Don Juan

DAVID SHENGOLD

Pushkin's The Bronze Horseman and Irving's "The Legend of Sleepy Hollow": A Curious Case of Cultural Cross-Fertilization? CATHARINE THEIMER NEPOMNYASHCHY

Love, Friendship, and Poetic Voice in Aleksandr Pushkin's Lycée Elegies JAMES L. MORGAN IV

Pushkin's Ironic Performances as a Gambler IAN M. HELFANT 
Writing the Story of Pushkin's Death

LESLIE O'BELL

The Patriots' Pushkin

WENDY SLATER

\section{REVIEW ESSAYS}

The New Academy Pushkin: Toward a Definitive Text ANDREW KAHN

Thus Spoke Moskovskii Pushkinist: Aleksandr Pushkin in Contemporary Russian Scholarship BRIAN HOROWITZ

Iurii Lotman's Pushkiniana IRINA REYFMAN

Aleksandr Sergeevich Pushkin on the World Wide Web: An Annotated Bibliography ANN MARSH-FLORES

\section{A. S. PUSHKIN}

V. E. Vatsuro, S. A. Fomichev, et al., eds., Pushkin v prizhiznennoi kritike: $1820-1827$, introduction by G. E. Potapova (Michael Wachtel)

Monika Greenleaf and Stephen Moeller-Sally, eds., Russian Subjects: Empire, Nation, and the Culture of the Golden Age (Sarah Pratt)

G[ennadii] G[rigorievich] Krasukhin, Pushkin Boldino 1833. Novoe prochtenie: Mednyi usadnik, Pikovaia dama, Andzhelo, Osen' (Caryl Emerson)

Luc J. Beaudoin, Resetting the Margins: Russian Romantic Verse Tales and the Idealized Woman (Annette Pein)

Brett Cooke, Pushkin and the Creative Process (David M. Bethea)

Svetlana Evdokimova, Pushkin's Historical Imagination

(Monika Greenleaf)

Paul M. Austin, The Exotic Prisoner in Russian Romanticism (Katya Hokanson)

Tatiana Wolff, trans. and ed., Pushkin on Literature, rev. ed., with an introductory essay by John Bayley (Paul Debreczeny) 


\section{BOOK REVIEWS}

John Higley, Jan Pakulski, and Włodzimierz Wesołowski, eds., Postcommunist Elites and Democracy in Eastern Europe

(Herbert Kitschelt)

David A. Dyker, ed., The Technology of Transition: Science and Technology Policies for Transition Countries (Yakov M. Rabkin)

John Borneman, Settling Accounts: Violence, Justice, and Accountability in Postsocialist Europe (Claus Offe)

Manfred Wilke, ed., Anatomie der Parteizentrale: Die KPD/SED auf dem Weg zur Macht; Wilfried Loth, Stalin's Unwanted Child: The Soviet Union, the German Question and the Founding of the GDR, trans. Robert F. Hogg (R. C. Raack)

Hubert Orłowski, "Polnische Wirtschaft": Zum deutschen Polendiskurs der Neuzeit (Virginia R. Mitchell)

Jerzy Swięch, Literatura Polska w latach II wojny światowej (Bogdana Carpenter)

Andrew Felkay, Out of Russian Orbit: Hungary Gravitates to the West (Patrick H. O'Neil)

Péter Kaderjík and John Powell, eds., Economics for Environmental Policy in Transition Economies: An Analysis of the Hungarian Experience (Bruce Larson)

Dennis Deletant, Ceausescu and the Securitate: Coercion and Dissent in Romania, 1965-1989 (Frederick Kellogg)

Maria Todorova, Imagining the Balkans (Katherine Verdery)

James J. Sadkovich, The U.S. Media and Yugoslavia, 1991-1995 (Dona Kolar-Panov)

Alfonsas Eidintas, Vytautas Žalys, and Alfred Erich Senn, Lithuania in European Politics: The Years of the First Republic, 1918-1940, ed. Edvardas Tuskenis (Theodore R. Weeks)

Natalie Kononenko, Ukrainian Minstrels: And the Blind Shall Sing (Robert B. Klymasz)

Richard G. Hovannisian, ed., The Armenian People from Ancient to Modern Times. Vol. 2, Foreign Dominion to Statehood: The Fifteenth Century to the Twentieth Century (Rouben Paul Adalian)

Donald Ostrowski, Muscovy and the Mongols: Cross-Cultural Influences on the Steppe Frontier, 1304-1589 (Eve Levin)

John Cook, Voyages and Travels through the Russian Empire, Tartary, and Part of the Kingdom of Persia, 2 vols., ed. A. L. Fullerton (Michael Khodarkovsky) 
Jeffrey Burds, Peasant Dreams and Market Politics: Labor Migration and the Russian Village, 1861-1905 (Cathy A. Frierson)

Aleksandr Etkind, Khlyst: Sekty, literatura i revoliutsiia (Laura Engelstein)

Alessandro Stanziani, L'économie en revolution: Le cas russe, 1870-1930 (Thomas C. Owen)

Stefan Plaggenborg, Revolutionskultur: Menschenbilder und kulturelle Praxis in Sotvjetrussland zwischen Oktoberrevolution und Stalinismus (Michael David-Fox)

Jean-Paul Depretto, Les Ouvriers en U.R.S.S., 1928-1941, preface by René Girault (Kenneth M. Straus)

Harvey Klehr, John Earl Haynes, and Kyrill M. Anderson, The Soviet World of American Communism (Kevin McDermott)

486

Dennis J. Dunn, Caught between Roosevelt and Stalin: America's Ambassadors to Moscow (David S. Foglesong)

Aleksandr M. Nekrich, Pariahs, Partners, Predators: German-Soviet Relations, 1922-1941, ed. and trans. Gregory L. Freeze, foreword by Adam B. Ulam (Gabriel Gorodetsky)

Zvi Gitelman, ed., Bitter Legacy: Confronting the Holocaust in the USSR (Mark von Hagen)

Roland Dannreuther, The Soviet Union and the PLO (Galia Golan)

Mette Bryld and Erik Kulavig, eds., Soviet Civilization between Past and Present (Glennys Young)

Archie Brown, The Gorbachev Factor (T. H. Rigby) 493

Mary McAuley, Russia's Politics of Uncertainty (Timothy J. Colton) 494

Peter Kirkow, Russia's Provinces: Authoritarian Transformation versus Local Autonomy? (Kathryn Stoner-Weiss)

Elena Hellberg-Hirn, Soil and Soul: The Symbolic World of Russianness (Joanna Hubbs)

Peter I. Barta, David H. J. Larmour, and Paul Allen Miller, eds., Russian Literature and the Classics (Roberta Reeder)

Irina Paperno, Suicide as a Cultural Institution in Dostoevsky's Russia (Harriet Murav)

Natasha Sankovitch, Creating and Recovering Experience: Repetition in Tolstoy (Donna Orwin)

Stephen C. Hutchings, Russian Modernism: The Transfiguration of the Everyday (Steven Cassedy) 
Andrew Wachtel, ed., Petrushka: Sources and Contexts

(Evelyn Bristol)

Graham Roberts, The Last Soviet Avant-Garde. OBERIU_Fact, Fiction, Metafiction (Sarah Pratt)

M. Gor'kii, Polnoe sobranie sochinenii: Pis' ma v dvadtsati chetyrekh tomakh, vols. 1-3 (Barry P. Scherr)

Verena Krieger, Von der Ikone zur Utopie: Kunstkonzepte der Russischen Avantgarde (John E. Bowlt)

Tatiana K. Egorova, Soviet Film Music: An Historical Survey, trans. Tatiana A. Ganf and Natalia A. Egunova (James H. Krukones) 508

BOOKS RECEIVED 